\title{
Geological Lineament Pattern and Geomorphic Indices Characteristic Related to Geothermal Manifestation Appearance: A Case Study from Gunung Talang District and Its Surroundings, Solok Regency, West Sumatra Province, Indonesia
}

\author{
Jordi Andrifa, Nana Sulaksana, Dewi Gentana, Murni Sulastri
}

Faculty of Geological Engineering, Universitas Padjadjaran, Sumedang, Indonesia

\begin{abstract}
Article Info

Volume 8, Issue 3

Page Number : 323-336

Publication Issue

May-June-2021

Article History

Accepted : 18 May 2021

Published : 24 May 2021

The study area is located in Gunung Talang District and its surroundings, Solok Regency, West Sumatra Province, Indonesia. This area has a potential volcanic geothermal system and is generally covered by the Quarternary rocks which are deformed due to the tectonic activity of the Sumatran Fault System. Geological structure traces are not well preserved in such an area. This study aims to determine the geological lineament pattern associated with geological structure, the geomorphic indices characteristic related to the tectonic activity and rock permeability, and the geothermal manifestation appearance based on these two factors. Geological lineament pattern is identified using the remote sensing method. Geomorphic indices characteristic is calculated through the quantitative analysis of bifurcation ratio $\left(\mathrm{R}_{\mathrm{b}}\right)$, drainage density $\left(\mathrm{D}_{\mathrm{d}}\right)$, mountain front sinuosity $\left(\mathrm{S}_{\mathrm{mf}}\right)$, and lineament density $\left(\mathrm{Ld}_{\mathrm{d}}\right)$. Geothermal manifestation appearance is evaluated through geospatial analysis using the overlay method on the geological lineament pattern and the geomorphic indices characteristic, which are then correlated with the distribution of geothermal manifestations. The main geological lineament patterns associated with the geological structures in the study area are north-northwest-south-southeast (NNW-SSE) and northeast-southwest (NE-SW). These lineament patterns indicate synthetic and antithetic strike-slip faults around the Sumani Segment of Sumatran Fault System successively. The geomorphic indices characteristics imply deformed areas ( $\mathrm{R}_{\mathrm{b}}$ values: $\left.1.14-5.45\right)$, rough ( $\mathrm{D}_{\mathrm{d}}$ values: $\left.2.00-2.66 \mathrm{~km} / \mathrm{km}^{2}\right)$, moderate $\left(\mathrm{D}_{\mathrm{d}}\right.$ values: $3.14-4.00 \mathrm{~km} / \mathrm{km}^{2}$ ), and slightly fine landform textures ( $D_{d}$ values: 4.32 $5.51 \mathrm{~km} / \mathrm{km}^{2}$ ), active ( $\mathrm{S}_{\mathrm{mf}}$ values: $\left.1.05-1.64\right)$ and moderate to slightly active tectonisms ( $\mathrm{S}_{\mathrm{mf}}$ values: $\left.1.74-2.52\right)$, low ( $\mathrm{Ld}_{\mathrm{d}}$ values: $\left.0.00-0.84 \mathrm{~km}^{-1}\right)$, moderate $(\mathrm{Ld}$ values: $0.84-1.68 \mathrm{~km}^{-1}$ ), and high lineament densities ( $\mathrm{Ld}$ values: $1.68-2.52 \mathrm{~km}^{-1}$ ) over the study area. The geothermal manifestations in the study area are
\end{abstract}


divided into four groups based on their appearance characteristics, namely group I (Songsang and Garara hot springs), group II (Padang Damar, Bukit Gadang, and Batu Bajanjang hot springs), group III (Bukit Kili and Bawah Gunuang hot springs), and group IV (Gabuo Atas and Bawah Betung hot springs).

Keywords: Geological Lineament, Geomorphic Indices, Geothermal Manifestation, Gunung Talang

\section{INTRODUCTION}

Geothermal energy is the energy derived from heat sources beneath the earth's surface. This energy can be used as a renewable and eco-friendly source for producing electricity [1]. As a country with the largest geothermal energy resource potential, Indonesia has more than $29,000 \mathrm{MW}$ or approximately $40 \%$ of the world geothermal resources potential [2]. This potential is an implication of the complex interactions between the Indo-Australian, Eurasian, and Pacific Plates that have resulted in volcanic activity and major faults in Indonesia [3]. By the 13,470 MW geothermal potential for electricity generation, Sumatra Island has the largest accumulative geothermal potential over the other islands in Indonesia [4]. Gunung Talang - Bukit Kili is an area that has geothermal resource potential on this island, which is estimated to have the potential for electricity generation of $65 \mathrm{MW}$ [5]. The study area is administratively located in Gunung Talang and its surroundings, Solok Regency, West Sumatra Province, Indonesia (Figure. 1).

According to [6], the study area is relatively covered by the Quaternary volcanic rocks such as the Undifferentiated Volcanic Products (QTau), Welded Tuff (QTwt), Andesite of Gunung Talang (Qatg), and Alluvial Fans (Qf) (Figure 2). In addition, there are a few pre-Tertiary to Tertiary age rocks such as the
Slate and Shale Member of Tuhur Formation (Trts) and Andesite to Basalt (Ta) in the northwestern part of the study area. The study area is regionally influenced by tectonic activities such as magmatic arc and the active Sumatran Fault System [7]. Based on its geomorphic characteristic, this area is deformed by the Sumani Segment of the Sumatran Fault [8]. Based on the structural geology aspect, graben structures are common in the study area. Therefore, the geothermal system in the study area can be classified as a grabentype geothermal system [9].

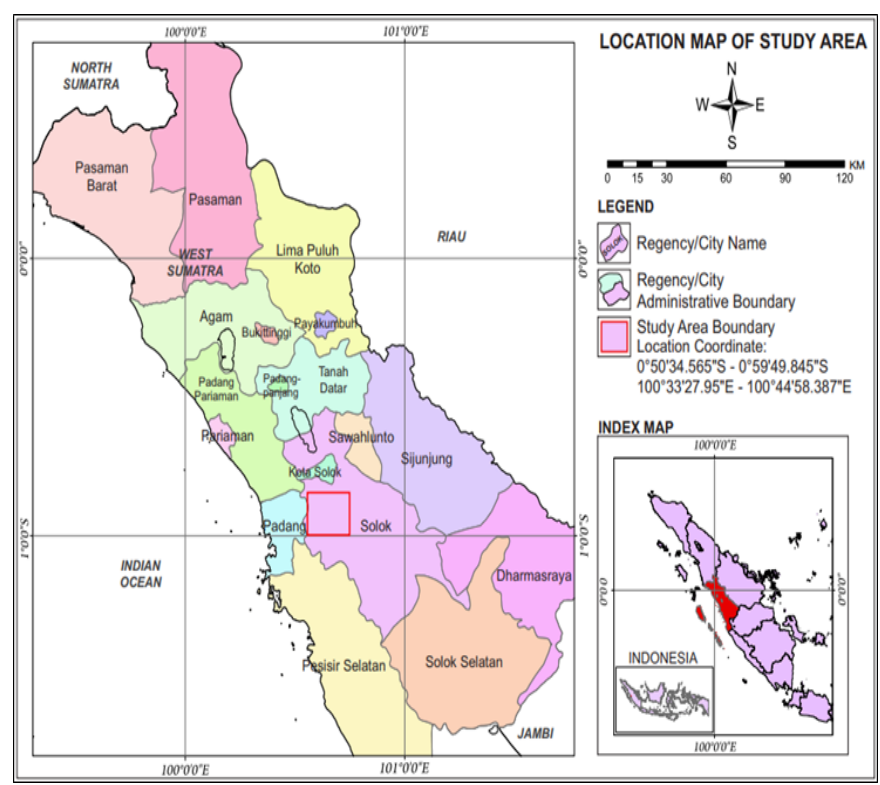

Figure 1: Location map of study area 


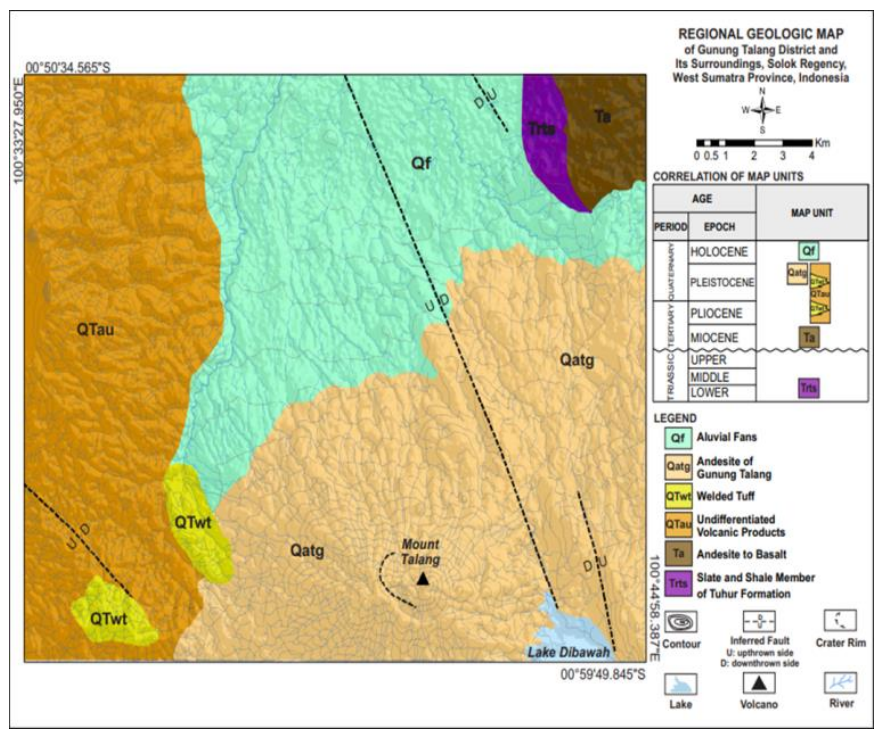

Figure 2: Regional geologic map of study area (modified from [6])

The existence of geothermal resources is usually indicated by the appearance of geothermal surface manifestations as a result of the heat propagation from the subsurface and the flow of geothermal fluid to the surface through the rock fractures [10]. The data gathered in [11] and [12] suggest that thirteen geothermal manifestation points in the study area are included as a hot spring type. Fracture is a geological structure that can be caused by rock deformation due to tectonic activity and igneous intrusion. It creates a permeable zone that can be a pathway for the flow of geothermal fluid from the reservoir to the surface. This permeable zone has proven to be a productive well drilling target in geothermal exploration and exploitation activities [13], [14] in [15].

Structural lineament analysis can provide an overview of local tectonic features and information about possible regional tectonic evolution [16]. The lineament pattern is useful for identifying the pattern of main geological structure which affects the distribution of geothermal manifestations [17]. A quantitative approach based on the geomorphic indices is used to increase the accuracy of geomorphological analysis, specifically in identifying tectonic activity and rock permeability in areas with Quaternary volcanic landforms. This approach is used because the traces of geological structures are not well preserved in Quaternary volcanic rocks, which are not yet fully compacted [18]. This study aims to evaluate geological lineament patterns associated with geological structures, tectonic activity, and rock permeability, especially around the appearance of geothermal manifestations, which indicate the geothermal potential in the study area.

\section{METHODS AND MATERIAL}

This study is conducted using data obtained from the Indonesian Terrain Map [19], Advanced Spaceborne Thermal Emission and Reflection Radiometer Global Digital Elevation Model (ASTER GDEM) [20], and previous researches. Geological lineament pattern is identified using remote sensing methods. Identification of geomorphic indices characteristic is carried out through quantitative analysis based on four parameters, namely bifurcation ratio $\left(\mathrm{R}_{\mathrm{b}}\right)$, drainage density $\left(\mathrm{D}_{\mathrm{d}}\right)$, mountain front sinuosity $\left(\mathrm{S}_{\mathrm{mf}}\right)$, and lineament density $\left(\mathrm{Ld}_{\mathrm{d}}\right)$. The appearance of geothermal manifestation is evaluated through geospatial analysis using the overlay method on the geological lineament pattern and the geomorphic indices characteristic which are then correlated with geothermal manifestation distribution.

\section{A. Geological Lineament Pattern}

The expression of geological lineament on the surface due to the reactivation of subsurface geological structures can reflect the lineament zones associated with broad geological structures. This feature can be identified at a certain edge that has a subtle brightness difference in the image. It can reflect the straight stream and valley, alignment in depressions, abrupt topographic changes, soil tonal changes, and alignment in vegetations [21] in [22]. Identification of this feature is carried out through shaded topographic relief created using certain apparent sun positions with a $45^{\circ}$ azimuth increment starting from the north. It aims to identify the lineament in all directions. Lowering vertical sun angle and superimposing 
detailed topographic contours can help to identify vague lineament [14]. Identified lineaments are depicted on a rose diagram to illustrate the main geological lineament patterns in the study area [17]. Structural patterns analysis in satellite imagery shows that lineament pattern can be classified into different groups based on their orientation [23]. The orientation and sense of strain of geological structures in the strike-slip fault zone associated with the en echelon arrangement are consistently arranged with respect to the principle displacement zone (PDZ) [24]. Hence, the structural pattern can be used for further interpretation of the geological structure by recognizing the PDZ in the study area.

\section{B. Geomorphic Indices}

1) Bifurcation Ratio $\left(R_{b}\right)$ : Bifurcation ratio $\left(R_{b}\right)$ is the ratio between the number of a certain order stream segment $\left(\sum \mathrm{N}_{\mathrm{u}}\right)$ and a higher-order stream segment $\left(\sum \mathrm{N}_{\mathrm{u}+1}\right)$. The $\mathrm{Rb}$ value is obtained using the following equation:

$\mathrm{R}_{\mathrm{b}}=\sum \mathrm{N}_{\mathrm{u}} / \sum \mathrm{N}_{\mathrm{u}+1}$

The watershed with a value of $\mathrm{R}_{b}<3.0$ or $\mathrm{R}_{\mathrm{b}}>5.0$ is indicated to have undergone deformation which is controlled by the tectonic activity, whereas the watershed with an $\mathrm{R}_{\mathrm{b}}$ value of 3.05.0 indicates that the area is not deformed by the tectonic activity [25] in [18].

2) Drainage Density $\left(D_{d}\right)$ : Drainage density $\left(D_{d}\right)$ is the ratio between the total length of streams $\left(\sum \mathrm{L}\right)$ and the watershed or sub-watershed area (A). The $D_{d}$ value is calculated using the following equation [26]:

$\mathrm{D}_{\mathrm{d}}=\sum \mathrm{L} / \mathrm{A}$

The $D_{d}$ value is useful for identifying the texture of Quarternary volcanic landform, namely very coarse ( $D_{d}$ values: $\left.0.00-1.37 \mathrm{~km} / \mathrm{km}^{2}\right)$, coarse $\left(D_{d}\right.$ values: $1.38-2.75 \mathrm{~km} / \mathrm{km}^{2}$ ), moderate ( $\mathrm{D}_{\mathrm{d}}$ values: $2.76-4.13 \mathrm{~km} / \mathrm{km}^{2}$ ), slightly fine ( $\mathrm{D}_{\mathrm{d}}$ values: $4.14-$ $5.51 \mathrm{~km} / \mathrm{km}^{2}$ ), fine ( $D_{d}$ values: $5.52-6.89 \mathrm{~km} / \mathrm{km}^{2}$ ), and very fine textures ( $D_{d}$ values: 6.90-8.27 $\mathrm{km} / \mathrm{km}^{2}$ ) [27] in [18]. The low $D_{d}$ values associated with coarse to medium landform textures indicate the presence of permeable rock under a watershed [28]. Meanwhile, the high $D_{d}$ value indicates impermeable rock beneath a watershed with a large number of streamflows on the surface [18].

3) Mountain Front Sinuosity $\left(\mathrm{S}_{\mathrm{mf}}\right)$ : Mountain front sinuosity $\left(\mathrm{S}_{\mathrm{mf}}\right)$ is a geomorphic index that explains the relationship between tectonic activity that forms a straight mountain front and the erosion process of a river that intersects mountain front [29] in [30]. The value of the mountain front sinuosity $\left(\mathrm{S}_{\mathrm{mf}}\right)$ can be obtained from the comparison between the length of the mountain front segment (Lmf) and the length of the projected mountain front segment (Ls), as expressed on the following equation:

$\mathrm{S}_{\mathrm{mf}}=\mathrm{Lmf} / \mathrm{L}$

The value of $S_{\mathrm{mf}}$ is useful to identify the tectonic activity such as active tectonism $\left(\mathrm{S}_{\mathrm{mf}}\right.$ values: 1.2 1.6), moderate to slightly active tectonism ( $\mathrm{S}_{\mathrm{mf}}$ values: $1.8-3.4)$, and tectonically inactive $\left(\mathrm{S}_{\mathrm{mf}}\right.$ values: 2.0-7.0) [29] in [31].

4) Lineament Density $(\mathrm{Ld})$ : Lineament density $(\mathrm{Ld})$ is the ratio between the total length of lineament (F) and the area of a calculation grid (A). Faults and fractures as products of tectonic activity can be used to identify geothermal fields using this parameter. A high lineament density indicates the presence of a permeable zone associated with geothermal reservoirs. The $\mathrm{Ld}$ value is calculated using the following equation:

$\mathrm{Ld}=\mathrm{F} / \mathrm{A}$

The calculation of lineament density uses a gridding system with a grid size of $1 \mathrm{x} 1 \mathrm{~km}^{2}$ as the area of calculation to obtain the lineament length per unit area $\left(\mathrm{km}^{-1}\right)$ at the centre point of each grid. The $\mathrm{Ld}$ value of each grid is useful to construct the contours illustrating the lineament density of an area [13]. Previous research around Mount Rendingan in Lampung Province, Indonesia showed areas with low lineament 
density $\left(\mathrm{Ld}\right.$ values $\left.<1.00 \mathrm{~km}^{-1}\right)$, moderate lineament density ( $\mathrm{Ld}$ values: $1.00-2.00 \mathrm{~km}^{-1}$ ), and high lineament density ( $\mathrm{Ld}$ values: $2.00-3.00 \mathrm{~km}^{-1}$ ) [32].

\section{RESULTS AND DISCUSSION}

\section{A. Geological Lineament Pattern}

Lineament pattern depiction on the rose diagram in the map of geological lineament pattern shows that relatively there are two main patterns in the study area, namely the northwest-southeast (NW-SE) and northeast-southwest (NE-SW) patterns (Figure 3). The northwest-southeast (NW-SE) lineament pattern indicates a strike-slip fault in the principle displacement zone (PDZ) and synthetic strike-slip faults with north-northwest-south-southeast (NNWSSE) and northwest-southeast (NW-SE) patterns. The northeast-southwest (NE-SW) lineament pattern indicates antithetic strike-slip faults with a northeastsouthwest (NE-SW) and north-northeast-southsouthwest (NNE-SSW) patterns. Moreover, there are circular patterns associated with crater or caldera remnants that indicate past volcanic activity.

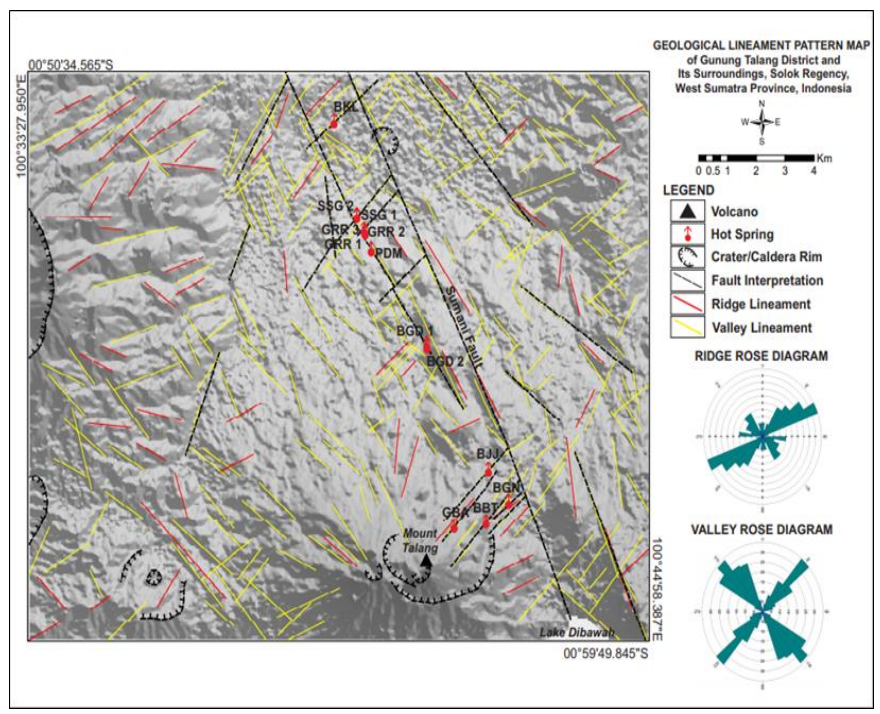

Figure 3: Geological lineament pattern map and rose diagram of study area show the main lineament patterns, namely northwest-southeast (NW-SE) and northeast-southwest (NE-SW), as the indication of structural patterns associated with the appearance of geothermal manifestations in the study area

\section{B. Geomorphic Indices}

1) Bifurcation Ratio $\left(R_{b}\right)$ : The bifurcation ratio of seventeen sub-watersheds in the study area has the $\mathrm{R}_{\mathrm{b}}$ values range from 1.14 to 5.45 (Table 1 ). There are seven sub-watersheds in the Batang Sumani watershed with the $\mathrm{R}_{\mathrm{b}}$ values range from 1.14 to 2.17. In the Air Bartumbuh watershed, there are five sub-watersheds with the $\mathrm{R}_{\mathrm{b}}$ values range from 1.78 to 5.01. In the Batang Lembang watershed, there are five sub-watersheds with the $\mathrm{R}_{\mathrm{b}}$ values range from 1.68 to 5.45 . Based on the classification of $R_{b}$ values [25] in [18], all subwatersheds in the study area are inferred to have undergone deformation controlled by the tectonic activity.

TABLE I

THE RESULT OF BIFURCATION RATIO $\left(\mathrm{R}_{\mathrm{b}}\right)$

CALCULATION AND ITS SIGNIFICATION

\begin{tabular}{|c|c|c|c|c|c|c|c|c|c|c|c|c|}
\hline \multirow{2}{*}{ Watershed } & \multirow{2}{*}{$\begin{array}{c}\text { Sub- } \\
\text { Water- } \\
\text { shed }\end{array}$} & \multicolumn{5}{|c|}{$\begin{array}{l}\text { Segment Number } \\
\text { of Stream Order }\end{array}$} & \multicolumn{4}{|c|}{$R_{b}$ Value } & \multirow{2}{*}{\begin{tabular}{|c|}
$R_{\mathrm{b}}$ \\
Mean \\
Value
\end{tabular}} & \multirow{2}{*}{ Signification } \\
\hline & & $1^{\text {st }}$ & $2^{\text {nd }}$ & $3^{\text {rd }}$ & $4^{\text {th }}$ & $5^{\text {th }}$ & 1-2 & $2-3$ & $3-4$ & $4-5$ & & \\
\hline \multirow{7}{*}{$\begin{array}{l}\text { Batang } \\
\text { Sumani }\end{array}$} & \begin{tabular}{|l|} 
SW 1 \\
\end{tabular} & \begin{tabular}{|l|}
402 \\
\end{tabular} & 196 & 116 & 50 & 37 & 2.05 & 1.69 & 2.32 & 1.35 & 1.85 & Deformed \\
\hline & SW 2 & 293 & 131 & 97 & 40 & 17 & 2.24 & 1.35 & 2.43 & 2.35 & 2.09 & Deformed \\
\hline & SW 3 & \begin{tabular}{|l|l|}
63 \\
\end{tabular} & 42 & 18 & & & 1.50 & 2.33 & & & 1.92 & Deformed \\
\hline & SW 4 & 22 & 12 & 8 & & & 1.83 & 1.50 & & & 1.67 & Deformed \\
\hline & SW 5 & 21 & 10 & 8 & & & 2.10 & 1.25 & & & 1.68 & ned \\
\hline & SW 6 & 8 & 7 & & & & 1.14 & & & & 1.14 & ned \\
\hline & SW 13 & 29 & 17 & 8 & 3 & & 1.71 & 2.13 & 2.67 & & 2.17 & Deformed \\
\hline \multirow{5}{*}{$\begin{array}{c}\text { Air } \\
\text { Bartumbuh }\end{array}$} & SW 7 & 28 & 13 & 9 & 5 & & 2.15 & 1.44 & 1.80 & & 1.80 & Deformed \\
\hline & SW 8 & 44 & 19 & 9 & 15 & 1 & 2.32 & 2.11 & 0.60 & 15.00 & 5.01 & Deformed \\
\hline & SW 9 & 21 & 6 & 12 & 4 & & 3.50 & 0.50 & 3.00 & & 2.33 & med \\
\hline & \begin{tabular}{|l|} 
SW 14 \\
\end{tabular} & 10 & 6 & 3 & & & 1.67 & 2.00 & & & 1.83 & ned \\
\hline & SW 15 & 19 & 11 & 6 & & & 1.73 & 1.83 & & & 1.78 & Deformed \\
\hline \multirow{5}{*}{$\begin{array}{l}\text { Batang } \\
\text { Lembang }\end{array}$} & SW 10 & 21 & 8 & 11 & & & 2.63 & 0.73 & & & 1.68 & Deformed \\
\hline & SW 11 & 23 & 10 & & 13 & & 2.30 & & & & 2.30 & Deformed \\
\hline & SW 12 & 115 & 60 & 32 & 5 & 18 & 1.92 & 1.88 & 6.40 & 0.28 & 2.62 & Deformed \\
\hline & SW 16 & 24 & 15 & 5 & 4 & & 1.60 & 3.00 & 1.25 & & 1.95 & Deformed \\
\hline & SW 17 & 36 & 20 & 13 & 1 & & 1.80 & 1.54 & 13.00 & & 5.45 & Deformed \\
\hline
\end{tabular}

The geothermal manifestations in the study area appear in deformed sub-watersheds with the $\mathrm{Rb}$ values ranging from 1.68 to 2.33 and 5.01 (Figure 4). Bukit Kili (BKL) hot spring appears in SubWatershed 8 (SW 8) with an $\mathrm{R}_{b}$ value of 5.01. Songsang (SSG), Garara (GRR), and Padang Damar (PDM) hot springs appear in SubWatershed 9 (SW 9) with an $\mathrm{Rb}$ value of 2.33. 
Bukit Gadang (BGD) hot springs appear in SubWatershed 14 (SW 14) with an $\mathrm{R}_{b}$ value of 1.83 . Batu Bajanjang (BJJ) hot spring appears in SubWatershed 10 (SW 10) with an $\mathrm{R}_{\mathrm{b}}$ value of 1.68). Bawah Gunuang (BGN), Gabuo Atas (GBA), and Bawah Betung (BBT) hot springs appear in SubWatershed 16 (SW 16) with an $\mathrm{R}_{\mathrm{b}}$ value of 1.95.

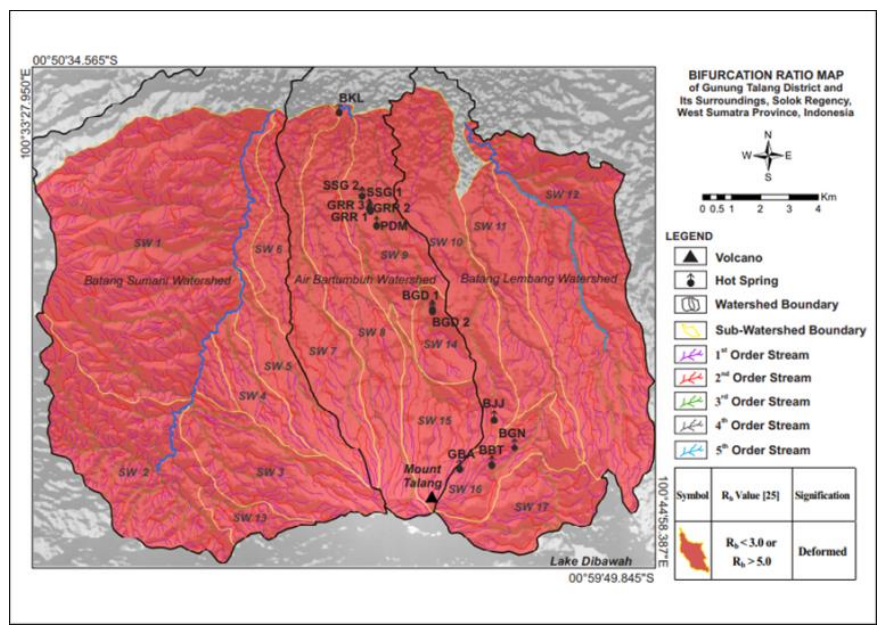

Figure 4: Bifurcation ratio $(\mathrm{Rb})$ map of seventeen subwatersheds shows the influence of deformation due to the tectonic activity related to the appearance of geothermal manifestation in the study area

2) Drainage Density $\left(D_{d}\right)$ : The drainage density of seventeen sub-watersheds in the study area has $D_{d}$ values range from 2.00 to $5.51 \mathrm{~km} / \mathrm{km}^{2}$. Based on the textural classification of Quarternary volcanic landform, [27] in [18], a coarse, moderate, and slightly fine landform texture has developed in the study area (Table 2). Batang Sumani watershed with the $\mathrm{D}_{\mathrm{d}}$ values ranging from 2.03 to $5.51 \mathrm{~km} / \mathrm{km}^{2}$ mainly consists of sub-watersheds with a slightly fine landform texture. In comparison, Air Bartumbuh watershed with the $D_{d}$ values ranging from 2.34 to $3.90 \mathrm{~km} / \mathrm{km}^{2}$ and Batang Lembang watershed with the $D_{d}$ values ranging from 2.00 to $4.00 \mathrm{~km} / \mathrm{km}^{2}$ mainly consist of sub-watersheds with moderate and coarse landform textures. Geothermal manifestations appear in these two watersheds. Based on [18] and [28], a high $D_{d}$ value indicates low rock permeability, while a low $D_{d}$ value indicates high rock permeability. Therefore, it can be seen that the sub-watersheds with a coarse landform texture in the study area (viz., SW 6, SW 9, SW 10, SW 11, and SW 14) are associated with relatively high rock permeability zone, subwatersheds with a moderate landform texture in the study area (viz., SW 5, SW 7, SW 8, SW 12, SW 15, SW 16, and SW 17) are associated with relatively moderate rock permeability zone, while sub-watersheds with a slightly fine landform texture in the study area (viz., SW 1, SW 2, SW 3, SW 4, and SW 13) are associated with relatively low rock permeability zone.

\section{TABLE II}

THE RESULT OF DRAINAGE DENSITY (Dd CALCULATION AND ITS SIGNIFICATION

\begin{tabular}{|c|c|c|c|c|c|}
\hline Watershed & $\begin{array}{c}\text { Sub- } \\
\text { Watershed }\end{array}$ & $\begin{array}{l}\text { Total } \\
\text { Length of } \\
\text { Streams } \\
\text { (? L) }\end{array}$ & $\begin{array}{c}\text { Area } \\
\text { (A) }\end{array}$ & $\begin{array}{c}\text { Drainage } \\
\text { Den sity } \\
\left(D_{d}\right)\end{array}$ & $\begin{array}{c}\text { Landform } \\
\text { Texture }\end{array}$ \\
\hline \multirow{7}{*}{$\begin{array}{l}\text { Batang } \\
\text { Sumani }\end{array}$} & SW 1 & 264.79 & 61.06 & 4.34 & Slightly Fine \\
\hline & SW 2 & 128.44 & 24.12 & 5.33 & Slightly Fine \\
\hline & SW 3 & 67.51 & 15.05 & 4.49 & Slightly Fine \\
\hline & SW 4 & 22.69 & 5.25 & 4.32 & Slightly Fine \\
\hline & SW 5 & 31.44 & 8.44 & 3.73 & Moderate \\
\hline & SW 6 & 11.82 & 5.82 & 2.03 & Coarse \\
\hline & SW 13 & 17.76 & 3.22 & 5.51 & Slightly Fine \\
\hline \multirow{5}{*}{$\begin{array}{c}\text { Air } \\
\text { Bartumbuh }\end{array}$} & SW 7 & 46.36 & 14.75 & 3.14 & Moderate \\
\hline & SW 8 & 66.22 & 19.36 & 3.42 & Moderate \\
\hline & SW 9 & 31.29 & 13.39 & 2.34 & Coarse \\
\hline & SW 14 & 12.87 & 4.83 & 2.66 & Coarse \\
\hline & SW 15 & 38.03 & 9.74 & 3.90 & Moderate \\
\hline \multirow{5}{*}{$\begin{array}{l}\text { Batang } \\
\text { Lembang }\end{array}$} & SW 10 & 38.70 & 19.37 & 2.00 & Coarse \\
\hline & SW 11 & 35.56 & 13.37 & 2.66 & Coarse \\
\hline & SW 12 & 134.35 & 37.74 & 3.56 & Moderate \\
\hline & SW 16 & 33.02 & 8.25 & 4.00 & Moderate \\
\hline & SW 17 & 36.99 & 9.95 & 3.72 & Moderate \\
\hline
\end{tabular}

Geothermal manifestations in the study area appear in sub-watersheds with moderate to coarse landform textures ( $D_{d}$ values: $2.00-4.00 \mathrm{~km} / \mathrm{km}^{2}$ (Figure 5). The geothermal manifestations appeared in the coarse landform texture consist of Songsang (SSG), Garara (GRR), and Padang Damar (PDM) hot springs distributed in SubWatershed 9 (SW 9) with a $D_{d}$ value of 2.34 $\mathrm{km} / \mathrm{km}^{2}$, Bukit Gadang (BGD) hot springs distributed in Sub-Watershed 14 (SW 14) with a $D_{d}$ value of $2.66 \mathrm{~km} / \mathrm{km}^{2}$, and Batu Bajanjang (BJJ) 
hot spring located in Sub-Watershed 10 (SW 10) with a $D_{d}$ value of $2.00 \mathrm{~km} / \mathrm{km}^{2}$. Meanwhile, the geothermal manifestations appeared in the moderate landform texture consist of Bukit Kili (BKL) hot spring located in Sub-Watershed 8 (SW 8) with a $D_{d}$ value of $3.42 \mathrm{~km} / \mathrm{km}^{2}$, Bawah Gunuang (BGN), Gabuo Atas (GBA), and Bawah Betung (BBT) hot springs distributed in SubWatershed 16 (SW 16) with a $D_{d}$ value of 4.00 $\mathrm{km} / \mathrm{km}^{2}$. Sub-watersheds with a slightly fine landform texture ( $D_{d}$ values: $4.32-5.51 \mathrm{~km} / \mathrm{km}^{2}$ ) are inferred to have a relatively low rock permeability so that it cannot flow the geothermal fluid up to the earth's surface.

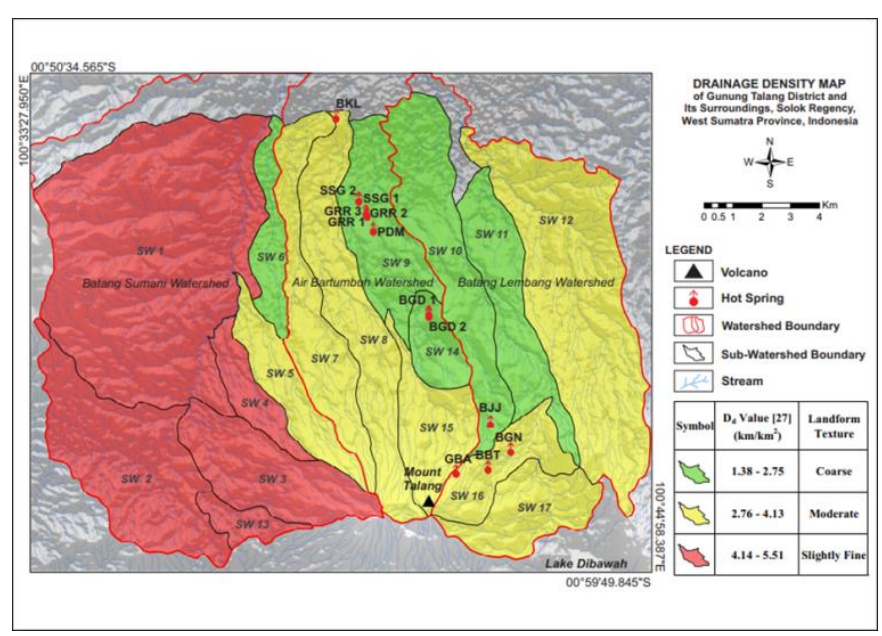

Figure 5: Drainage Density $\left(D_{d}\right)$ map of seventeen sub-watersheds shows that the landform textures associated with the appearance of geothermal manifestation in the study area are the coarse and moderate textures

3) Mountain Front Sinuosity ( $\left.\mathrm{S}_{\mathrm{mf}}\right)$ : The mountain front sinuosity of thirty-eight mountain front segments in the study area has $S_{\mathrm{mf}}$ values ranging from 1.05 to 2.52. Based on the classification of $S_{\mathrm{mf}}$ value [29] in [31], thirty-three mountain front segments indicate active tectonisms with the $\mathrm{S}_{\mathrm{mf}}$ values range from 1.05 to 1.64 , while five mountain front segments indicate moderate to slightly active tectonisms with the $\mathrm{S}_{\mathrm{mf}}$ values range from 1.74 to 2.52 (Table 3 ).
TABLE III

THE RESULT OF MOUNTAIN FRONT SINUOSITY ( $\left.\mathrm{S}_{\mathrm{mf}}\right)$ CALCULATION AND ITS SIGNIFICATION

\begin{tabular}{|c|c|c|c|c|}
\hline No. & L $_{\mathrm{mf}}$ & $\mathrm{L}_{\mathrm{s}}$ & $\mathrm{S}_{\mathrm{mf}}$ & Tectonic Activity \\
\hline 1 & 6.71 & 2.66 & 2.52 & $\begin{array}{c}\text { Moderate to } \\
\text { Slightly Active }\end{array}$ \\
\hline 2 & 7.34 & 4.04 & 1.82 & $\begin{array}{c}\text { Moderate to } \\
\text { Slightly Active }\end{array}$ \\
\hline 3 & 3.61 & 2.35 & 1.54 & Active \\
\hline 4 & 4.51 & 2.38 & 1.90 & $\begin{array}{c}\text { Moderate to } \\
\text { Slightly Active }\end{array}$ \\
\hline 5 & 7.43 & 5.38 & 1.38 & Active \\
\hline 6 & 3.38 & 2.40 & 1.41 & Active \\
\hline 7 & 4.27 & 2.20 & 1.94 & $\begin{array}{c}\text { Moderate to } \\
\text { Slightly Active }\end{array}$ \\
\hline 8 & 2.93 & 2.24 & 1.30 & Active \\
\hline 9 & 5.06 & 3.10 & 1.64 & Active \\
\hline 10 & 2.28 & 1.86 & 1.23 & Active \\
\hline 11 & 4.03 & 2.79 & 1.45 & Active \\
\hline 12 & 3.56 & 3.12 & 1.14 & Active \\
\hline 13 & 2.44 & 1.87 & 1.30 & Active \\
\hline 14 & 9.37 & 5.95 & 1.58 & Active \\
\hline 15 & 2.69 & 2.17 & 1.24 & Active \\
\hline 16 & 3.04 & 2.55 & 1.19 & Active \\
\hline 17 & 3.73 & 2.65 & 1.41 & Active \\
\hline 18 & 8.99 & 6.83 & 1.32 & Active \\
\hline 19 & 6.05 & 4.01 & 1.51 & Active \\
\hline 20 & 1.53 & 1.24 & 1.23 & Active \\
\hline 21 & 2.54 & 2.20 & 1.16 & Active \\
\hline 22 & 2.73 & 2.35 & 1.16 & Active \\
\hline 23 & 1.73 & 1.41 & 1.23 & Active \\
\hline 24 & 2.52 & 2.04 & 1.23 & Active \\
\hline 25 & 4.69 & 2.70 & 1.74 & $\begin{array}{c}\text { Moderate to } \\
\text { Slightly Active }\end{array}$ \\
\hline 26 & 6.51 & 4.50 & 1.45 & Active \\
\hline 27 & 4.02 & 2.62 & 1.53 & Active \\
\hline 28 & 4.41 & 3.04 & 1.45 & Active \\
\hline 29 & 3.96 & 2.67 & 1.48 & Active \\
\hline 30 & 7.18 & 5.14 & 1.40 & Active \\
\hline 31 & 3.29 & 2.67 & 1.23 & Active \\
\hline 32 & 2.31 & 1.63 & 1.42 & Active \\
\hline 33 & 1.58 & 1.21 & 1.30 & Active \\
\hline 34 & 2.62 & 2.11 & 1.24 & Active \\
\hline 35 & 3.63 & 2.45 & 1.48 & Active \\
\hline 36 & 3.47 & 3.01 & 1.15 & Active \\
\hline 37 & 3.96 & 3.02 & 1.31 & Active \\
\hline 38 & 3.24 & 3.08 & 1.05 & Active \\
\hline
\end{tabular}

Geothermal manifestations in the study area appear around the mountain front segments, 
which indicate active tectonisms with the $\mathrm{S}_{\mathrm{mf}}$ values ranging from 1.16 to 1.58 (Figure 6). Bukit Kili (BKL) hot spring appears around segment 14 with an $\mathrm{S}_{\mathrm{mf}}$ value of 1.58. Songsang (SSG) and Garara (GRR) hot springs appear around segment 15 with an $\mathrm{S}_{\mathrm{mf}}$ value of 1.24. Padang Damar (PDM) hot spring appears in segment 16 with an $\mathrm{S}_{\mathrm{mf}}$ value of 1.19. Bukit Gadang (BGD) hot springs appear in segment 18 with an $S_{\mathrm{mf}}$ value of 1.32 . Batu Bajanjang (BJJ) hot spring appears in segment 32 with an $\mathrm{S}_{\mathrm{mf}}$ value of 1.42. Bawah Gunuang (BGN) hot spring appears in segment 33 with an $\mathrm{S}_{\mathrm{mf}}$ value of 1.30. Gabuo Atas (GBA) hot spring appears in segment 21 with an $\mathrm{S}_{\mathrm{mf}}$ value of 1.16. Bawah Betung (BBT) hot spring appears in segment 34 with an $\mathrm{S}_{\mathrm{mf}}$ value of 1.24.

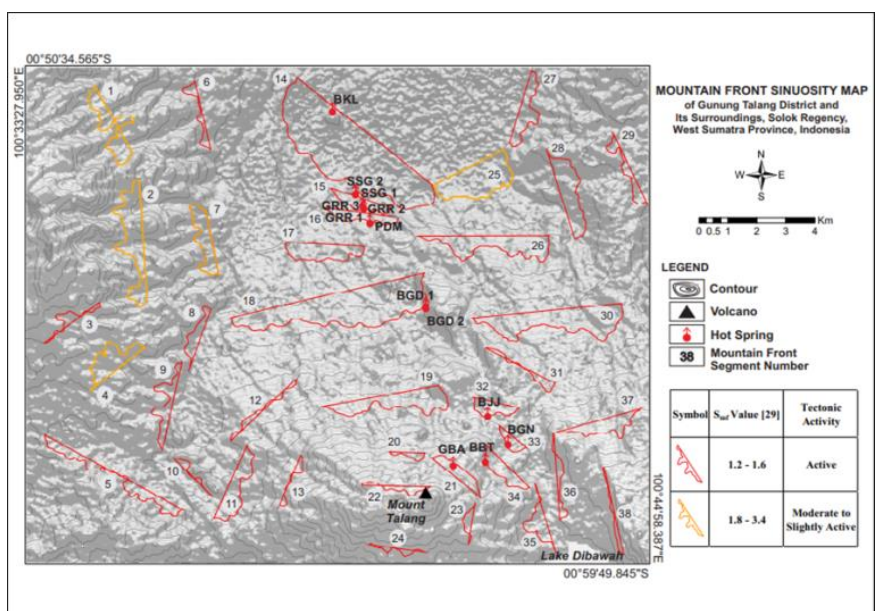

Figure 6: Mountain front sinuosity $\left(\mathrm{S}_{\mathrm{mf}}\right)$ map of the study area shows the appearance of geothermal manifestations around the mountain front segments indicating active tectonisms

4) Lineament Density ( $\mathrm{Ld}_{\mathrm{d}}$ ): The lineament density analysis shows the distribution of low to high lineament density zones in the study area with the $\mathrm{Ld}_{\mathrm{d}}$ values ranging from 0.00 to $2.52 \mathrm{~km}^{-1}$. According to [13] and [14], high lineament density indicates the presence of a permeable zone. Therefore it can be seen that the study area consists of: the low lineament density areas associated with relatively low rock permeability zones, which are represented by dark to light green colour ( $\mathrm{Ld}$ values: $0.00-0.84 \mathrm{~km}^{-1}$ ); the moderate lineament density areas associated with relatively moderate rock permeability zones, which are represented by light to dark yellow colour ( $\mathrm{Ld}_{\mathrm{d}}$ values: $0.84-1.68 \mathrm{~km}^{-1}$ ); and the high lineament density areas associated with relatively high rock permeability zones, which are represented by light to dark orange colour ( $\mathrm{Ld}_{\mathrm{d}}$ values: $1.68-2,52 \mathrm{~km}^{-1}$ ).

Geothermal manifestations in the study area appear in the moderate to high lineament density areas with the $\mathrm{Ld}_{\mathrm{d}}$ values range between 1.26 and $2.52 \mathrm{~km}^{-1}$ (Figure 7). Bukit Kili (BKL), Songsang (SSG), Garara (GRR), and Bawah Gunuang (BGN) hot springs appear in the high lineament density areas with the $\mathrm{Ld}$ values range from 1.68 to 2.52 $\mathrm{km}^{-1}$. Meanwhile, Padang Damar (PDM), Bukit Gadang (BGD), Batu Bajanjang (BJJ), Gabuo Atas (GBA), and Bawah Betung (BBT) hot springs appear in the moderate lineament density areas with the $\mathrm{Ld}$ values range from 1.26 to $1.68 \mathrm{~km}^{-1}$. The low lineament density areas with the $\mathrm{Ld}_{\mathrm{d}}$ values range between 0.00 and $0.84 \mathrm{~km}^{-1}$ is inferred to have a low fault and fracture intensity associated with an impermeable zone that has a low capability to flow the geothermal fluid up to the earth's surface.

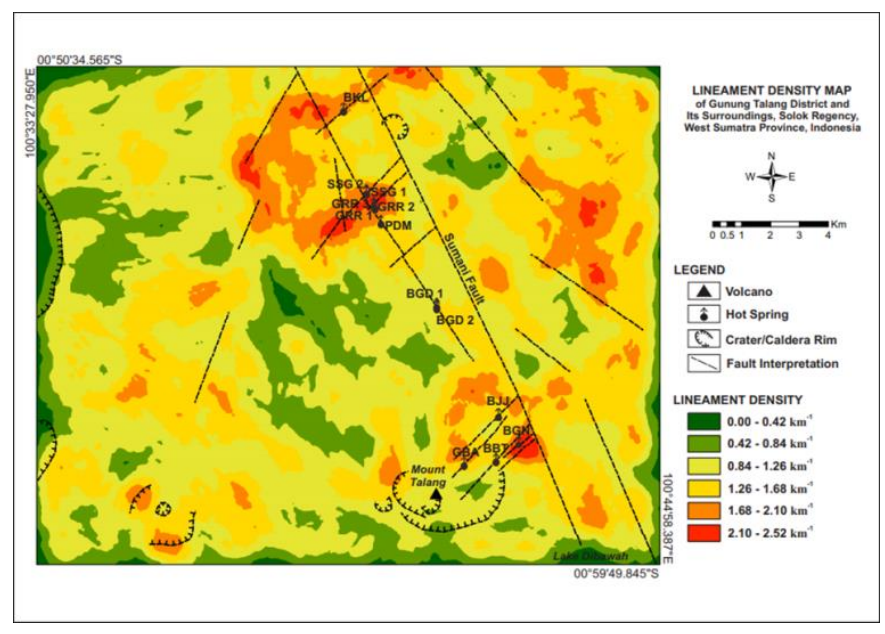

Figure 7: Lineament density $\left(\mathrm{Ld}_{\mathrm{d}}\right)$ map of the study area shows the appearance of geothermal manifestations in the moderate to high lineament density areas 


\section{Geothermal Manifestation Appearance}

The analysis of geological lineament pattern shows that the geothermal manifestation appearance in the study area is associated with geological structures that have relatively north-northwest-south-southeast (NNW-SSE) and northeast-southwest (NE-SW) patterns. These structural patterns indicate synthetic and antithetic strike-slip faults developed around the Sumani Segment of Sumatran Fault, which causes rock deformation to form permeable zones that have a high capability to flow the geothermal fluid up to the earth's surface. The calculation of the geomorphic indices using the parameters of the bifurcation ratio $\left(\mathrm{R}_{\mathrm{b}}\right)$ and the mountain front sinuosity $\left(\mathrm{S}_{\mathrm{mf}}\right)$ shows the similarity on the appearance of geothermal manifestations, which is distributed in the areas that have undergone deformation due to active tectonism. The calculations of drainage density $\left(\mathrm{D}_{\mathrm{d}}\right)$ and lineament density $(\mathrm{Ld})$ parameters show characteristic variations on the appearance of geothermal manifestations, which are appeared in the areas with moderate to coarse landform textures and medium to high lineament densities, associated with relatively moderate to high rock permeability zones. These findings suggest that the geothermal manifestations in the study area are divided into four groups, namely group I, II, III, and IV (Table 4).

\section{TABLE IV}

GEOTHERMAL MANIFESTATION GROUP

BASED ON THE GEOLOGICAL LINEAMENT

PATTERN AND THE GEOMORPHIC INDICES CHARACTERISTIC OF THE STUDY AREA

\begin{tabular}{|c|c|c|c|c|c|}
\hline \multirow[b]{2}{*}{$\begin{array}{c}\text { Geothermal } \\
\text { Manifestation } \\
\text { Group }\end{array}$} & \multirow[b]{2}{*}{$\begin{array}{c}\text { Geological } \\
\text { Lineament } \\
\text { Pattem }\end{array}$} & \multicolumn{4}{|c|}{ Geomorphic Indices Characteristic } \\
\hline & & $\begin{array}{c}\text { Tectonic } \\
\text { Deformation } \\
\left(\mathbf{R}_{\mathbf{b}}\right)\end{array}$ & $\begin{array}{c}\text { Landform } \\
\text { Texture } \\
\left(D_{d}\right)\end{array}$ & $\begin{array}{c}\text { Tectonic } \\
\text { Activity } \\
\left(\mathrm{S}_{\mathrm{mf}}\right)\end{array}$ & $\begin{array}{c}\text { Lineament } \\
\text { Density } \\
\left(\mathrm{L}_{\mathrm{d}}\right)\end{array}$ \\
\hline I & $\begin{array}{l}\text { NNW-SSE } \\
\text { NE-SW }\end{array}$ & $\begin{array}{c}\text { Deformed } \\
(2.33)\end{array}$ & $\begin{array}{l}\text { Coarse } \\
(2.34)\end{array}$ & $\begin{array}{l}\text { Active } \\
(1.24)\end{array}$ & $\begin{array}{c}\text { High } \\
(1.68-2.52)\end{array}$ \\
\hline II & $\begin{array}{c}\text { NNW-SSE } \\
\text { NE-SW }\end{array}$ & $\begin{array}{c}\text { Deformed } \\
(1.68-2.33)\end{array}$ & $\begin{array}{c}\text { Coarse } \\
(2.00-2.66)\end{array}$ & $\begin{array}{c}\text { Active } \\
(1.19-1.42)\end{array}$ & $\begin{array}{c}\text { Moderate } \\
(1.26-1.68)\end{array}$ \\
\hline III & NE-SW & $\begin{array}{c}\text { Deformed } \\
(1.95-5.01)\end{array}$ & $\begin{array}{c}\text { Moderate } \\
(3.42-4.00)\end{array}$ & $\begin{array}{c}\text { Active } \\
(1.30-1.58)\end{array}$ & $\begin{array}{c}\text { High } \\
(1.68-2.52)\end{array}$ \\
\hline IV & NE-SW & $\begin{array}{c}\text { Deformed } \\
(1.95)\end{array}$ & $\begin{array}{c}\text { Moderate } \\
(4.00)\end{array}$ & $\begin{array}{c}\text { Active } \\
(1.16-1.24)\end{array}$ & $\begin{array}{l}\text { Moderate } \\
(1.26-1.68)\end{array}$ \\
\hline
\end{tabular}

1) Group I Geothermal Manifestation: The geothermal manifestations of group I are illustrated by yellow manifestation symbols in the overlay map. This group manifestations consist of the Songsang (SSG) and Garara (GRR) hot springs. The geothermal manifestations of this group appear in areas with the presence of: fault intersections with the north-northwest-southsoutheast (NNW-SSE) and northeast-southwest (NE-SW) patterns, rock deformation with an $\mathrm{R}_{\mathrm{b}}$ value of 2.33, coarse landform texture with a $D_{d}$ value of $2.34 \mathrm{~km} / \mathrm{km}^{2}$, active tectonism with an $\mathrm{S}_{\mathrm{mf}}$ value of 1.24, and high lineament density with the $\mathrm{Ld}$ values range from 1.68 to $2.52 \mathrm{~km}^{-1}$. In brief, the group I geothermal manifestations appear on the Alluvial Fans (Qf) unit [6] at SubWatershed 9 (SW 9), which have undergone deformation due to active tectonism associated with relatively high rock permeability zone.

2) Group II Geothermal Manifestation: The geothermal manifestations of group II are illustrated by blue manifestation symbols in the overlay map. This group manifestations consist of the Padang Damar (PDM), Bukit Gadang (BGD), and Batu Bajanjang (BJJ) hot springs. The geothermal manifestations of this group appear in areas with the presence of: faults with the northnorthwest-south-southeast (NNW-SSE) and northeast-southwest (NE-SW) patterns, rock deformations with the $\mathrm{R}_{b}$ values range from 1.68 to 2.33 , coarse landform textures with the $D_{d}$ values range from 2.00 to $2.66 \mathrm{~km} / \mathrm{km}^{2}$, active tectonisms with the $\mathrm{S}_{\mathrm{mf}}$ values ranges from 1.19 to 1.42 , and moderate lineament densities with the $\mathrm{Ld}$ values range from 1.26 to $1.68 \mathrm{~km}^{-1}$. In brief, the group II geothermal manifestations appear on the Alluvial Fans (Qf) and Andesite of Gunung Talang (Qatg) unit [6] at Sub-Watershed 9 (SW 9), Sub-Watershed 10 (SW 10), and SubWatershed 14 (SW 14), which have undergone deformation due to active tectonism associated 
with relatively moderate to high rock permeability zones.

3) Group III Geothermal Manifestation: The geothermal manifestations of group III are illustrated by purple manifestation symbols in the overlay map. This group manifestations consist of Bukit Kili (BKL) and Bawah Gunuang (BGN) hot springs. The geothermal manifestations of this group appear in areas with the presence of: faults with the northeast-southwest (NE-SW) pattern, rock deformations with the $\mathrm{R}_{\mathrm{b}}$ values range from 1.95 to 5.01, moderate landform textures with the $D_{d}$ values range from 3.42 to $4.00 \mathrm{~km} / \mathrm{km}^{2}$, active tectonisms with the $\mathrm{S}_{\mathrm{mf}}$ values range from 1.30 to 1.58, and high lineament densities with the $\mathrm{Ld}$ values range from 1.68 to $2.52 \mathrm{~km}^{-1}$. In brief, the group III geothermal manifestations appear on the Alluvial Fans (Qf) and Andesite of Gunung Talang (Qatg) unit [6] at Sub-Watershed 8 (SW 8) and Sub-Watershed 16 (SW 16), which have undergone deformation due to active tectonism associated with relatively moderate to high rock permeability zones.

4) Group IV Geothermal Manifestation: The geothermal manifestations of group IV are illustrated by black manifestation symbols in the overlay map. This group manifestations consist of Gabuo Atas (GBA) and Bawah Betung (BBT) hot springs. The geothermal manifestations of this group appear in areas with the presence of: faults with the northeast-southwest (NE-SW) pattern, rock deformation with an $\mathrm{R}_{b}$ value of 1.95, moderate landform texture with a $D_{d}$ value of 4.00 $\mathrm{km} / \mathrm{km}^{2}$, active tectonism with the $S_{\mathrm{mf}}$ values range from 1.16 to 1.24 , and moderate lineament density with the $\mathrm{Ld}_{d}$ values range from 1.26 to 1.68 $\mathrm{km}^{-1}$. In brief, the group IV geothermal manifestations appear on Andesite of the Gunung Talang (Qatg) unit [6] at Sub-Watershed 16, which has undergone deformation due to active tectonism associated with relatively moderate rock permeability zones.
The distribution of the geothermal manifestation groups and their appearance characteristics are shown on the overlay map of geological lineament pattern and geomorphic indices characteristic of the study area (Figure 8).

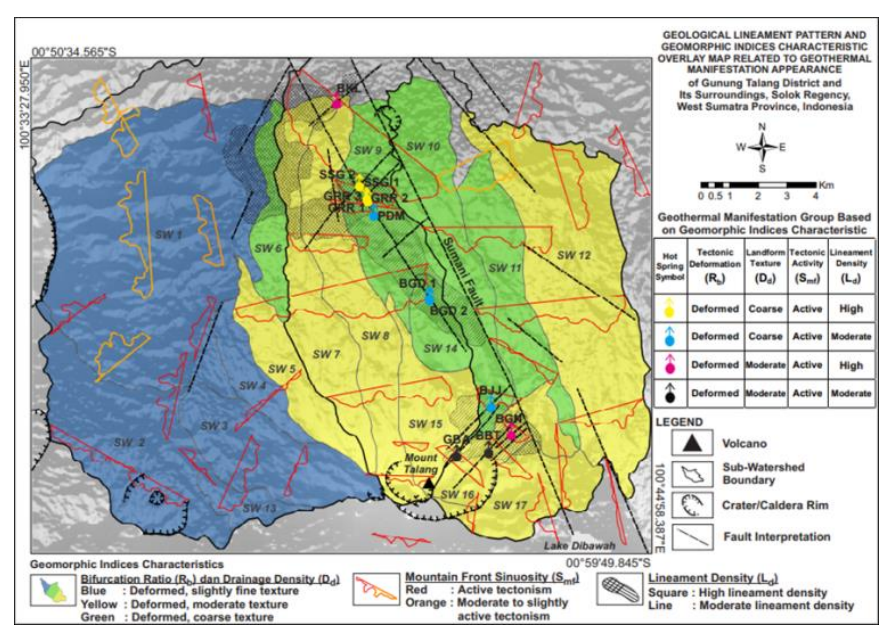

Figure 8: Geological lineament pattern and geomorphic indices characteristic overlay map shows the distribution of the geothermal manifestation groups and their appearance characteristics

\section{CONCLUSION}

Gunung Talang District and its surroundings are generally covered with the Quaternary volcanic rocks which are deformed by the tectonic activity of the Sumatran Fault System. In this paper, we have presented a case study of the study area about the geological lineament pattern and geomorphic indices characteristics related to the appearance of geothermal manifestations. The results of remote sensing analysis suggest that the geological lineament patterns associated with the main geological structures in the study area are north-northwestsouth-southeast (NNW-SSE) and northeast-southwest (NE-SW). These lineament patterns indicate synthetic and antithetic strike-slip faults around the Sumani Segment of Sumatran Fault System successively. In general, the results of quantitative analysis of geomorphic indices indicate deformed areas ( $\mathrm{R}_{\mathrm{b}}$ values: 1.14-5.45), coarse ( $\mathrm{D}_{\mathrm{d}}$ values: $2.00-2.66 \mathrm{~km} / \mathrm{km}^{2}$ ), 
moderate ( $D_{d}$ values: $3.14-4.00 \mathrm{~km} / \mathrm{km}^{2}$ ), and slightly fine landform textures ( $D_{\mathrm{d}}$ values: $4.32-5.51 \mathrm{~km} / \mathrm{km}^{2}$ ), active ( $\mathrm{S}_{\mathrm{mf}}$ values: $\left.1.05-1.64\right)$ and moderate to slightly active tectonisms ( $\mathrm{S}_{\mathrm{mf}}$ values: $\left.1.74-2.52\right)$, and low $\left(\mathrm{Ld}_{\mathrm{d}}\right.$ values: $\left.0.00-0.84 \mathrm{~km}^{-1}\right)$, moderate ( $\mathrm{L}_{\mathrm{d}}$ values: $0.84-1.68$ $\mathrm{km}^{-1}$ ), and high lineament densities ( $\mathrm{L}_{\mathrm{d}}$ values: 1.68$2.52 \mathrm{~km}^{-1}$ ) over the study area. The evidence from the study integrated by the geospatial analysis implies that the geothermal manifestations in the study area are divided into four groups based on their appearance characteristics. These groups are group I (Songsang and Garara hot springs), group II (Padang Damar, Bukit Gadang, and Batu Bajanjang hot springs), group III (Bukit Kili and Bawah Gunuang hot springs), and group IV (Gabuo Atas and Bawah Betung hot springs). It is necessary to both confirm the results of this study and understand the subsurface condition of the study area through geological and geophysical field investigations in the future.

\section{ACKNOWLEDGMENT}

The authors would like to show gratitude to the Dean of Faculty of Geological Engineering, Universitas Padjadjaran, for facilitating the study. This study was made possible by the L. Austin Weeks (LAW) Undergraduate Grant from AAPG Foundation. The authors sincerely acknowledge the Geospatial Information Agency of the Republic of Indonesia and NASA EOSDIS Land Processes DAAC of the U.S. Department of the Interior for providing the Indonesian Terrain Map and ASTER GDEM as the primary data sources used in this study. The authors would like to extend their sincere thanks to Mr Dalli Burhan from Universitas Andalas and Ms Fauzia Aulia Rachmawati from Universitas Padjadjaran for their previous researches providing the distribution of geothermal manifestation location as the secondary data used in this study. The authors also appreciate the unknown referee's valuable and profound comments. The authors themselves don't have any conflict of interest.

\section{REFERENCES}

[1]. M. F. Umam, F. Muhammad, D. W. Adityatama, and D. P. Purba, "Tantangan pengembangan energi panas bumi dalam perannya terhadap ketahanan energi di Indonesia," Swara Patra, vol. 8, no. 3, September, 2018. [Online Serial]. Available:

http://ejurnal.ppsdmmigas.esdm.go.id/sp/index.p hp/swarapatra/article/view/6. [Accessed: January 14, 2021].

[2]. D. Sukarna, "Development of geothermal policies, potential resources and implementation target," presented at Indo EBTKE Conference and Exhibition, Jakarta, Indonesia, 2012.

[3]. M. Boedihardi, A. Mulyono, A. Ginting, M. D. Mosby, and V. T. Radja, "Geology, energy potential and development of Indonesia's geothermal prospects," Bulletin of the Geological Sociecty of Malaysia, no. 33, p. 369, November 1993. [Abstract]. Available: AAPG Datapages, https://archives.datapages.com/data/geologicalsociety-ofmalaysia/bulletins/033/033001/pdfs/369.htm. [Accessed January 14, 2021].

[4]. A. F. Z and J. Hutahaean, "Penentuan struktur bawah permukaan tanah daerah potensi panas bumi dengan metode geomagnetik di Tinggi Raja Kabupaten Simalungun," Jurnal Einstein, vol. 3, no. 12, December, 2015. [Online Serial]. Available:

https:/jurnal.unimed.ac.id/2012/index.php/einst en/article/view/5444/8429. [Accessed: January 14, 2021].

[5]. L. Putriyana and H. Soekarno, "Numerical modelling of geothermal reservoir in Gunung Talang, West Sumatera, Indonesia," RISET Geologi dan Pertambangan, vol. 30, no. 1, June, 2020. [Online Serial]. Available: https://jrisetgeotam.lipi.go.id/index.php/jrisgeota $\mathrm{m} /$ article/view/1058. [Accessed: January 16, 2021]. 
[6]. P. H. Silitonga and Kastowo. Geological Map of the Solok Quadrangle, Sumatera, 2nd ed, scale 1:250.000. Bandung: Geological Research and Develompent Centre, 1995.

[7]. A. Munandar, E. Suhanto, D. Kusnadi, A. Idral, dan M. Solaviah, "Penyelidikan terpadu daerah panas bumi Gunung Talang Kabupaten Solok Sumatera Barat," presented at Mineral Resources Inventory Activity Result Colloquium, Bandung, Indonesia, 2003.

[8]. K. Sieh and D. Natawidjaja, "Neotectonics of Sumatran Fault, Indonesia," Journal of Geophysical Research, vol. 105, no. B12, December, 2000. [Online Serial]. Available: https://agupubs.onlinelibrary.wiley.com/doi/abs/ 10.1029/2000JB900120. [Accessed: January 19, 2021].

[9]. D. Santoso, M. E. Suparka, S. Sudarman, and S. Suari, "The geothermal fields in central part of the Sumatra Fault Zone as derived from geophysical data," presented at World Geothermal Congress, Florence, Italy, 1995.

[10]. N. M. Saptadji, Teknik Panas Bumi. Bandung: ITB Press, 2001.

[11].D. Burhan, "Pemetaan tipe mata air panas di Sumatera Barat (Studi kasus: 46 mata air panas di Kabupaten Pasaman, Pasaman Barat, Lima Puluh Kota, Agam, Tanah Datar, Solok, Sijunjung, dan Kabupaten Solok Selatan)," B.S. thesis, Dept. Phys., Univ. Andalas, Padang, Indonesia, 2017.

[12]. F. A. Rachmawati, A. D. Haryanto, J. Hutabarat, and M. Sumaryadi, "Penentuan sumber panas sistem panas bumi Gunung Api Talang, Sumatera Barat berdasarkan sejarah panas dan geokimia air," Padjadjaran Geoscience Journal, vol. 3, no. 1, February, 2019. [Online Serial]. Available: http://jurnal.unpad.ac.id/geoscience/article/view/ 20841. [Accessed: January 12, 2021].

[13].S. Soengkono, “Te Kopia geothermal system (New Zealand)—the relationship between its structure and extent," Geothermics, vol. 28, no. 6, pp. 780-782, 1999.
[14].S. Soengkono, "Analysis of digital topographic data for exploration and assessment of geothermal system," In Proc. 21st New Zealand Geothermal Workshop, 1999, pp. 163-166.

[15]. Suryantini and H. H. Wibowo, "Application of fault and fracture density (FFD) method for geothermal exploration in non-volcanic geothermal system: a case study in SulawesiIndonesia," In Proc. World Geothermal Congress, 2010, p. 1.

[16]. N. Sulaksana and A. H. Hamdani, "The analysis of remote sensing imagery for predicting structural geology in Berau Basin East Kalimantan," International Journal of Science and Research, vol. 3, no. 4, April, 2014. [Online Serial]. Available: https://www.ijsr.net/get_count.php?paper_id=20 131349. [Accessed: January 21, 2021].

[17]. D. Hermawan dan Y. Rezky, "Delineasi daerah prospek panas bumi berdasarkan analisis kelurusan citra landsat di Candi UmbulTelomoyo, Provinsi Jawa Tengah," Buletin Sumber Daya Geologi, vol. 6, no. 1, May, 2011. [Online Serial]. Available: http://buletinsdg.geologi.esdm.go.id/index.php/b sdg/article/view/92. [Accessed: January 21, 2021].

[18].E. Sukiyah, Eds., Sistem Informasi Geografis: Konsep dan Aplikasinya dalam Analisis Geomorfologi Kuantitatif, 1st ed. Bandung: Unpad Press, 2017.

[19]. Peta Rupa Bumi Digital Indonesia, Badan Informasi Geospasial Republik Indonesia, 2015$2019 . \quad$ [Online]. Available: http://tanahair.indonesia.go.id/portal-web/.

[Accessed: January 25, 2021].

[20]. ASTER Global Digital Elevation Model V003, NASA/METI/AIST/Japan Spacesystems and U.S./Japan ASTER Science Team, distributed by NASA EOSDIS Land Processes DAAC, 2019, [Online]. Available: https://doi.org/10.5067/ASTER/ASTGTM.003. [Accessed: January 25, 2021]. 
[21].J. P. Richards, "Lineaments revisited," Society of Economic Geologists Newsletter, vol. 42, no. 1, pp. 14-20, 2000.

[22].L. Q. Hung, O. Batelaan, and F. D. Smedt, "Lineament extraction and analysis, comparison of LANDSAT ETM and ASTER imagery. Case study: Suoimuoi tropical karst catchment, Vietnam," In Proc. SPIE, presented at the Remote Sensing for Environmental Monitoring, GIS Applications, and Geology, SPIE, 2005, p. 59830T-1.

[23]. Jamal, N. Sulaksana, E. Sukiyah, and Y. A. Sendjaja, "Analisis multi raster SRTM, radarsat dan landsat untuk karakterisisasi morfo-struktur dari geometri sesar di Daerah Binuang, Kalimantan Selatan, Jurnal Geologi dan Sumberdaya Mineral, vol. 20, no. 1, February, 2019. [Online Serial]. Available: https://jgsm.geologi.esdm.go.id/index.php/JGSM/ article/view/405. [Accessed: January 27, 2021].

[24].P. A. Allen and J. R. Allen, Basin Analysis: Principles and Applications, 2nd ed. Malden, MA: Blackwell Publishing, 2005.

[25].H. T. Verstappen, Applied Geomorphology: Geomorphological Surveys for Environmental Development. New York: Elsevier Science Publishing Company Inc, 1983.

[26]. R. E. Horton, "Erosional development of stream and their drainage basins: a hydrophysical approach to quantitative morphology," Geological Society of America Bulletin, vol. 56, no. 3, p. 283, 1945.

[27].E. Sukiyah, "The erosion model of the Quarternary volcanic terrain in southern part of Bandung Basin,” Ph.D. dissertation, Dept. Geol. Eng., Univ. Padjadjaran, Sumedang, Indonesia, 2009.

[28]. D. Gentana, N. Sulaksana, E. Sukiyah, and E. T. Yuningsih, "Index of active tectonic assessment: quantitative-based geomorphometric and morphotectonic analysis at Way Belu Drainage Basin, Lampung Province, Indonesia,"
International Journal of Advanced Science Engineering Information Technology, vol. 8, no. 6, December, 2018. [Online Serial]. Available: http://www.insightsociety.org/ojaseit/index.php/i jaseit/article/view/6089. [Accessed: February 2, 2021].

[29].W. B. Bull and L. D. McFadden, "Tectonic geomorphology north and south of the Garlock fault, California," in Geomorphology in Arid Regions. Proceedings of the Eighth Annual Geomorphology Symposium, 1st ed., D. O. Doehring, Eds. New York: Routledge, 1997, pp. 115-137.

[30]. N. Sulaksana, Supriyadi, Ismawan, P. P. R. Rendra, and M. Sulastri, "Active fault analysis through quantitative assesment method in Cikapundung Sub Watershed," International Journal of Scientific Research in Science and Technology, vol. 3, no. 6, July, 2017. [Online Serial]. Available: https://ijsrst.com/IJSRST173634. [Accessed: February 5, 2021].

[31]. J. C. Doornkamp, "Geomorphological approaches to the study of neotectonics," Journal of the Geological Society, 143, pp. 335-336, 1986.

[32]. D. Gentana, N. Sulaksana, E. Sukiyah, and E. T. Yuningsih, "Morphotectonics of Mount Rendingan Area related to the appearances of geothermal surface manifestations," Indonesian Journal on Geoscience, vol. 6, no. 3, December, 2019. [Online Serial]. Available: http://ijog.bgl.esdm.go.id/index.php/IJOG/article/ view/509. [Accessed: February 8, 2021]. 


\section{Cite this Article}

Jordi Andrifa, Nana Sulaksana, Dewi Gentana, Murni Sulastri, "Geological Lineament Pattern and Geomorphic Indices Characteristic Related To Geothermal Manifestation Appearance: A Case Study from Gunung Talang District and Its Surroundings, Solok Regency, West Sumatra Province, Indonesia", International Journal of Scientific Research in Science and Technology (IJSRST), Online ISSN : 2395-602X, Print ISSN : 2395-6011, Volume 8 Issue 3, pp. 323336, May-June 2021. Available at doi : https://doi.org/10.32628/IJSRST218358

Journal URL : https://ijsrst.com/IJSRST218358 